\title{
Judicial Independence: New Challenges in Established Nations
}

\author{
MARTIN SHAPIRO*
}

\begin{abstract}
Because courts are both conflict-resolving and lawmaking bodies, they should be both independent and accountable. This paradox of incidence and accountability cannot be resolved but only addressed by various and shifting pragmatic accommodations between independence and accountability. Prosecutors, trial courts, appeals courts, and constitutional courts are each subject to differing consideration in arriving at such accommodations.

Moreover, courts, as courts of law, are not independent but are agents of statutory and constitutional lawmakers. Excessive emphasis on judicial independence creates the danger that authoritarian regimes may achieve a cloak of legitimacy for their laws by having them enforced by independent judiciaries.
\end{abstract}

\section{INTRODUCTION}

Among a number of global quests in search of the rule of law, due process, and legal protection of human rights has been the quest for judicial independence. The banner of independence is waved by the right as a protection for investors and property more generally, by the left as essential for the judicial protection of human rights, and by champions of constitutional judicial review, as a constitutional court without independence would be a mere façade. Yet things are not so simple. Judicial independence is as much a problem as a solution. ${ }^{1}$ The

* Professor of Law, Emeritus; School of Law, University of California, Berkeley; Jurisprudence and Social Policy Program. B.A., UCLA 1955; Ph.D, Harvard University 1961.

1. See generally JUDICIAL INDEPENDENCE AT THE CROSSROADS: AN INTERDISCIPLINARY APPROACH (Stephen B. Burbank \& Barry Friedman eds., 2002); JUDICIAL INDEPENDENCE IN THE AGE OF DEMOCRacy (Peter H. Russell \& David M. O'Brien eds., 2001); G. AlaN TARR, WITHOUT FEAR OR FAVOR: JUDICIAL INDEPENDENCE AND JUDICIAL ACCOUNTABILITY in The States (2012); The Politics of Judicial IndEPENDENCE: CouRTS, Politics, AND

Indiana Journal of Global Legal Studies Vol. 20, Issue 1 (2013)

(C) Indiana University Maurer School of Law 
central task of judges is to resolve disputes. Independence is essential to the success of that mission. Judges, however, do not only resolve disputes. Judicial courts are "courts of law" that resolve disputes according to the law. To settle disputes judges must indubitably interpret what the law is. Whoever interprets the law or says what a legal text means, to some degree, at some times, and under some circumstances, makes the law. If judges make law, they must not be absolutely independent. They must be accountable to someone, at least according to any political theory currently at play in the politically developed world. Once independence and accountability are seen as two sides of the judicial coin, answers to questions about how independent courts should be are not so simple. Independence and accountability constitute an antinomy subject to pragmatic compromise rather than simple answers. The politically developed nations have devised various compromises, but none of them are completely satisfactory. ${ }^{2}$

Particularly, when mixed groups of Anglo-American and civil law scholars discuss judicial independence, they tend to conflate and confuse a number of different conceptions of judicial office and function. Some additional clarity, if not resolution of this confusion, may be gained by carefully distinguishing between the various and sometimes differing functions labeled "judicial" in various legal systems.

\section{THE ROLE OF PROSECUTORS}

One of the great divides between Anglo-American and civil law systems involves criminal investigation and prosecution. Although subject to various modifications and reforms, in civil law systems the development of the investigative record leading to prosecution and the decision whether to prosecute typically lies in the hands of government officers who are labeled judges. In some instances these officers rotate between judicial duties and those of investigation and prosecution, and in other instances the officers are separated from the rest of the judiciary, but nonetheless hold a judicial title. In common law systems, criminal investigation and prosecution are never in the hands of judges.

Looking more closely at pretrial activity, sometimes labeled judicial activity, we discover a number of different functions that raise somewhat diverse issues of judicial independence. First is the decision

The Public (Bruce Peabody ed., 2011); Mitchel A. Sollenberger, Judicial APPOINTMENTS AND DEMOCRATIC Controls (2011); Paul D. Carrington, Judicial Independence and Democratic Accountability in Highest State Courts, 61 LAW \& CONTEMP. PROBS. 79 (1998).

2. See generally JUDICIAL INDEPENDENCE AT THE CROSSROADS: AN INTERDISCIPLINARY APPROACH, supra note 1. 
to prosecute, which rests in part on an assessment of whether there is sufficient evidence against the accused to make it reasonably likely that he would be found guilty in a trial. This assessment is essentially "judicial" in the sense that it involves the prosecutor weighing the evidence for and against the suspect and anticipating the decision of the trial judge or jury, using the same standards of admissibility and proof that they would use in a trial. ${ }^{3}$ Indeed, in theory at least, while the prosecutor may be making a decision fraught with uncertainty, it is not a discretionary decision. If there is sufficient weight of evidence to justify a conviction, the prosecutor has a legal duty to prosecute. Because the decision to prosecute is judicial in this sense, it is generally considered that it ought to be independent.

In reality, however, the decision to prosecute inevitably also rests on balancing the investigation and litigation resources available to the prosecutor against the demands that are made on those resources. Few societies are willing to devote the necessary amount of public resources to properly prepare and carry out the prosecution of every criminal act that could reasonably be assigned to a particular suspect. Prosecution involves priorities and the assignment of limited resources so as to optimize, but not fully achieve, public purposes or policies. Thus, the decision whether to prosecute is not fully, or solely, judicial, but is, to some degree, executive. It rests not only on the perceived guilt or innocence of the accused, but on the relative importance to the achievement of crime control of pursuing one particular prosecution rather than others. Such a decision about allocation of organizational resources is essentially executive, rather than judicial, and because those resources are public and devoted to public purposes, they are essentially political. This is why common law systems use election or political appointment of prosecutors.

Finally, the decision to prosecute involves not only who to prosecute but what sentence to seek-that is, what crime to charge and what level of punishment to seek. In theory, these prosecutorial choices in civil law systems are not discretionary but dictated in the same way judges' and juries' decisions are-by the weight of the admissible evidence. However, the reality is that scarcity of prosecutorial resources and the uncertainties of predicting actual trial court outcomes inevitably lead to some level of charge or sentence plea bargaining between the prosecutor and the defendant. Also, the degree to which considerations of organizational resources, goals, and prestige are at play in such

3. See generally Bruce A. Green \& Fred C. Zacharias, Prosecutorial Neutrality, 2004 WIS. L. REV. 837 (2004) (discussing the role prosecutorial discretion plays in criminal law enforcement). 
prosecutorial bargaining might reasonably be said to be executive rather than judicial.

\section{THE ROLE OF TRIAL COURT JUdgeS}

If we move from prosecutors labeled as judges to actual trial court judges, the nature of discretion and the balance between discretion and legally predetermined decisions changes. While admitting all of the unavoidable human elements that the judicial realists taught us enter into judicial decisions, surely the decision of guilt, innocence, or other legal culpability is supposed to be law driven rather than discretionary. Judges, however, also make a great many procedural decisions often decisive to trial court outcomes. In some sense, many of these decisions are discretionary, involving close calls as to what the law demands. However, these decisions remain largely judicial in the sense that they are decisions about what the law requires even when the law's demand may only be "fairness." The trial judge in both jury and nonjury systems is the very prototype of a judge, the guardian and applier of the law to a particular conflict and, therefore, in need of independence.

In some legal systems, all sentencing is specifically legally mandated. In others, judges have wide sentencing discretion. Obviously, there are many intermediate positions. Also, in some instances, judges may find criminal defendants guilty of a lesser included offense and not guilty of the most serious offense, may set the amount of damages, or may frame remedial orders so as to subject the losing defendant to more or less severe deprivations. ${ }^{4}$ To some degree, sentencing decisions may involve various considerations of public policy, such as ease of enforcement or deterrent effect, but the dominant factor is likely to be assessment of individual culpability and/or mitigation, and therefore, seem to fall within the judicial realm to be shielded by judicial independence.

\section{THE ROLE OF APPELLATE COURT JUDGES}

Appeals courts present quite a different problem from that of trial courts. To be sure, much of what appellate courts do is simply review what trial courts have done. Appellate judges act judicially, reviewing the decisions trial judges make. However, appeals courts also do a great deal of lawmaking, which is disguised and excused as "interpretation." Both trial and appeals courts "interpret" statutory text, but the final say

4. See generally SENTENCING AND SANCTIONS IN WESTERN CounTRIES (Michael Tonry $\&$ Richard S. Frase eds., 2001). 
in interpretation usually lies with appeals courts. Of course, great oceans of fashionable continental literary theory hold that the true meaning of all text lies in the hands, or minds, of the interpreters, not the writers. Where the text is law and the interpreter is a court endowed with legal authority, interpretation becomes not only literary cleverness, but it also becomes lawmaking. Even without succumbing to literary fashion, it is clear that the text of many statutes is written generally, is sometimes incomplete, and is often deliberately ambiguous. And the devil very often is in the details.

Whether or not particular judges want to make law, courts will often determine the ultimate meaning of statutes, and consequently, the specific impact of those statutes. Judges must interpret statutes in order to decide cases according to preexisting legal rules. The legitimacy of courts as independent, neutral conflict resolvers depends on judges deciding disputes according to preexisting legal rules. ${ }^{5}$ Therefore, judges will discover and announce specific, preexisting legal rules even in statutes that are very unclear, garbled, or ambiguous. ${ }^{6}$

There is a well-known debate about precedent in civil law systems. ${ }^{7}$ If court decisions are not treated as precedents, the legal outcomes of particular cases will not have general legal effects, and thus will not be true lawmaking. ${ }^{8}$ No matter the theory, civil law systems, in one way or another, do treat high court interpretations as more or less precedential, albeit not always openly.

If appeals courts make law, then appeals courts in democracies face a special independence problem that is quite different than the problems that prosecutors or trial courts face. Democracies may be more or less majoritarian, but all democracies are grounded in a basic premise that the laws are to be made by the people or their representatives. Lawmakers are supposed to be dependent on the electorate, as opposed to being independent. If judges make law, then judicial independence is a very problematic value in a democracy.

In many legal systems, appeals courts not only review trial court decisions, but also review actions of administrative agencies in a way that sometimes constitutes lawmaking. Either in a disguised or open

5. See generally Martin ShaPIRo, Courts: A Comparative and POlitiCal ANALYSIS 1-64 (1981) (discussing the prototypical court that involves "(1) an independent judge applying (2) preexisting legal norms after (3) adversary proceedings in order to achieve (4) a dichotomous decision in which one of the parties was assigned the legal right and the other found wrong.").

6. See generally Martin Shapiro, Judges as Liars, 17 HARV. J.L. \& PUB. PoL'Y 155 (1994) (stating that judges exist in a paradox where they must make law and claim they are basing their decisions on legal principles but still deny that they are making law).

7. See generally SHAPIRO, supra note 5 .

8. See generally id. 
form, such review is often substantive, as well as procedural. ${ }^{9}$ The reviewing court may hold that an agency's action violates a statute. ${ }^{10}$ In such instances, the court substitutes its own interpretation of the statute for that made by the agency. ${ }^{11} \mathrm{By}$ using such formulas as ultra vires, natural justice, proportionality, abuse of discretion, or arbitrary and capricious, the court may simply be disagreeing with the policy choices the agency has made. ${ }^{12}$ In all of these instances, we simply see rival lawmakers, administrative and judicial, at work, and therefore, a problematic situation for independence.

Finally, courts exercising constitutional judicial review powers on appeal or original jurisdiction may, even more conclusively, veto legislative or administrative lawmaking, or they may substitute their own. ${ }^{13}$ Because constitutions tend to be even more generally worded than statutes, judges engaged in constitutional interpretation are likely to exercise great lawmaking powers. ${ }^{14}$ These lawmaking powers are likely to raise particular problems for democracy because the demosthat is the voters or the people-will find it more difficult to override judicial constitutional lawmaking than judicial statutory lawmaking, which can be overridden by further legislation. Thus, we actually encounter at least four different levels of judicial independence problems: prosecutorial, trial court, appeals court, and constitutional court.

\section{RECENT CHALLENGES}

Recently, problems of judicial independence have been rendered more acute by four interrelated developments. First and foremost is the proliferation of judicial institutions charged with constitutional review defending division of powers principles and especially constitutional bills of rights and their equivalents. ${ }^{15}$ The great potential political impact of judicial decisions of this kind, their risk of raising conflicts between judges and the government or powerful, political movements,

9. See generally MARTIN SHAPIRO, WHO GUARDS THE GUARDIANS?: JUDICLAL CONTROL OF ADMINISTRATION (1988).

10. See generally id.

11. See generally id.

12. See generally id.

13. See generally Alec Stone SweEt, Governing with Judges: Constitutional POLITICS IN EUROPE (2000).

14. See generally id.

15. See generally Rule BY LAW: The Politics Of COUR'Ts In AUTHORITARIAN REgimes (Tom Ginsburg \& Tamir Moustafa eds., 2008); S'TONE SwEET, supra note 13; Martin Shapiro, The Globalization of Judicial Review, in LEGAL CULTURE AND THE LEGAL ProfESSION 119 (Lawrence M. Friedman \& Harry N. Scheiber eds., 1996). 
their seeming finality, and their capacity to attract media attention inevitably generate powerful threats to judicial independence, often couched as pleas for judicial restraint and increased concerns for judicial accountability.

The second development that has affected judicial independence is the increasing tendency for parties unsuccessful at pursuing their goals through the electoral, legislative, or administrative processes to seek policy change by judicial decision-a movement sometimes referred to as the "judicialization" or "juridification" of politics. ${ }^{16}$ Here, the potential political kickback from judicial intervention and the risk that, in popular perception, the judges will be seen as just another bunch of politicians subject to the same pressures as other politicians, is of increasing concern. For this reason, accountability issues have come to rival independence concerns.

The third development affecting judicial independence is the growing tendency to employ litigation to seek not only general policy benefits but also gratification of personal interests that has been labeled "adversarial legalism." 17 If judges are asked to settle more and more medical malpractice complaints, patent disputes, and so on, they necessarily become greater targets for outside manipulation by particular interest groups such as doctors or high powered digital technology entrepreneurs. The manipulation may take the form of conventional corruption, political pressure, and/or launching a public discourse of delegitimation. If the courts restructure political processes and/or dictate major public policies, how will they become legitimated in democracies in which political decisions belong to the people and their elected representatives? Why should judges not be exposed to popular control in democratic states?

The fourth development is the proliferation of national and transnational long-arm jurisdictions that allow courts to assert jurisdiction over persons now living in another place for events that may have occurred in yet a third place at an earlier time. Such trials, ${ }^{18}$ or merely beginning prosecutions, may have serious, even dire, consequences for persons and communities far beyond those of the courts involved, whose home communities may be entirely unaffected. ${ }^{19}$

16. See generally Martin Shapiro \& Alec Stone Sweet, On Law, Politics, ANd JUDICIALIZATION (2002).

17. See generally Robert Kagan, AdVERSARIal LEgalism: THe AMERICAN WAY OF LaW (2001); Daniel R. Kelemen, Eurolegalism: The Transformation OF LaW and REGULATION IN THE EUROPEAN UNION (2011).

18. A number of states now authorize their courts to hear "war crimes" or "tort" cases involving events that occurred in other countries.

19. For instance, the prosecution in Spain of a former Chilean dictator contributed to serious political disturbances in Chile. 
Those judges and communities may feel the warm glow of vindicating human rights, while others may feel the glow of their homes burning in the riots that the prosecutions have engendered.

Long-arm proliferation provides a happy hunting ground for favorable forum shopping by national and transnational nongovernmental organizations (NGOs) and individuals who feel denied justice in the communities where severe deprivations of human rights have occurred. Such jurisdictional extensions may upset delicate diplomatic negotiations. They may embarrass the home governments of the asserting courts which may, precisely because of judicial independence, have no power to control those courts. They may generate serious political consequences in far distant countries whose complex circumstances are far beyond the ken of the judges claiming jurisdiction. Those judges may be entirely unaccountable for the often unpredictable consequences they generate in those countries. Even without actual prosecutions, the existence of such jurisdictions may lead dictators to hold on until the bitter end at the cost of thousands of lives rather than take their ill-gotten gains and retire to their distant, sun-drenched villas.

Even the most independent judges experience at least some level of personal accountability for the damage they may do in their home communities simply because they reside in those communities. The accountability issue becomes particularly acute when prosecutors and judges are dealing with communities that they may never even visit. The accountability problem is further aggravated when the law enforced at a long arm's length is a vaguely-stated, rapidly-evolving law of international human rights. This type of law invites and requires a high degree of judicial lawmaking in a complex political realm that neither judges nor anyone else understands very well.

\section{The Intersection of Prosecution AND the Politics of CONSTITUTIONAL DEMOCRATS}

In relatively developed democratic states, the leading traditional problems of prosecutorial independence were potential excessive favoritism to the state and corruption of the state. These former problems engendered arrangements for partially segregating prosecutors from a ministry of justice or other direct executive control. These arrangements include the semiautonomous United States Attorney's offices within the U.S. federal government and the 
incorporation of European prosecutors into an independent judiciary. ${ }^{20}$ The U.S. system of independently elected state prosecutors and attorneys general is another mode of protection against executive control. It may well be that any or all of these devices have been relatively successful. Or, in the final analysis, such devices may matter much less than a strongly held public value against politically inspired prosecution and state repression.

The opposite danger that rich or otherwise powerful individuals and interests can shield themselves against merited prosecution by corrupting prosecutors is not really addressed by conventional independence devices. Corrupting one prosecutor who works on her own is obviously easier than corrupting one who is embedded in a whole bureaucratic structure designed to supervise and hold accountable a number of prosecutors. On the other hand, where partisan party politics is pervasive in government administration, it may be harder to corrupt an independent prosecutor than one who is part of a party-dominated executive. The degree of corruption difficulty depends on how much the parties are dominated by wealth, family, or other personal connections.

In places where prosecutors are chosen by partisan election, prosecutorial corruption will depend on how much the parties have been corrupted. In places where such elections are nonpartisan, the need to finance election campaigns may undercut the anticorruption check that popular elections are supposed to provide. Yet, prosecutorial election systems do provide continuous, high incentives for the media and prospective rival parties or individuals to monitor prosecutorial conduct.

Where organized crime is powerful and extraordinarily wealthy, corruption may be anticipated. The Italian move to extremely independent prosecutors surely has been a response to the earlier corrupt connections between the mafia and elected politicians. ${ }^{21}$ Paradoxically, the subsequent assassinations and attempted assassinations of Italian prosecutors are signs that prosecutorial independence has worked against corruption. If prosecutors could be bought, there would be no need to blow them up. Similarly, in a number of countries, the wars waged between the government and drug cartels would seem to indicate that even the enormous wealth of the drug lords has not led to the level of corruption in the justice system that might have been anticipated. For if that system were bought, it would not have to be fought.

20. See generally Giuseppe Di Federtco, Recruitment, Professional Evaluation AND CAREER OF JUDGES AND PROSECUTORS IN EUROPE (2005).

21. See generally Adriana Alberti, Political Corruption and the Role of Public Prosecutors in Italy, 24 CRIME L. \& SOC. CHANGE 273 (1996). 
Two problems, both involving the intersection of prosecution and the politics of constitutional democracies, are currently of particular interest. The first problem occurs when there is a strong suspicion that political chief executives, such as prime ministers or presidents, have committed a crime. This problem is well illustrated in the United States. In most American states, both local prosecutors and the Attorney General, the latter having little or no control over local prosecutors, are independently elected. Therefore, they are well placed to independently investigate and prosecute local government and state chief executives (mayors, governors, etc.).

Indeed, because many elected prosecutors and attorneys general see their positions as stepping stones to higher political office, they have a special interest in mounting high profile prosecutions. Prosecutors and attorneys general gain high levels of name recognition among voters because of these high profile prosecutions, and, thus, enhance their chances of later running successfully for other offices. The very elected status that renders prosecutors sufficiently independent to prosecute, however, contains a strong threat to that independence. If the prosecutor and the chief political executive are in the same political party and the prosecutor anticipates running later for other elected offices, he may be reluctant to weaken the party under whose banner he wishes to run in the future by prosecuting one of that party's leading figures. On the other hand, the election of prosecutors solves the problem of democratic accountability.

At the U.S. federal government level, the Attorney General is appointed by and serves at the pleasure of the president. The Attorney General is the minister of justice in the president's Cabinet. He is also the chief prosecutor, because prosecution is an executive, rather than judicial, function. Thus, the Attorney General's position has always been unclear. Is he "the president's lawyer," advising and representing the chief executive and utilizing the best legal defenses of presidential positions, or is the Attorney General, as chief prosecutor, bound to independently prosecute even the highest officers of government should they violate the law?

Currently, there is a great constitutional debate in the United States over "unitary" theories of the presidency.22 The debate questions whether all the powers vested in the executive branch by the Constitution and Congressional statutes "belong" to the sitting president, or whether some can be vested independently in lesser executive officers. Under the strictest unitary theory, the prosecution of

22. See generally Terry M. Moe, The Politicized Presidency, in THE NEW DIRECTION IN AMERICAN Politics 235 (John E. Chubb \& Paul E. Peterson eds., 1985). 
the president would be an absurdity. The president would literally be prosecuting himself, because it is the president who ultimately holds all powers of the executive branch, including the Attorney General's power to prosecute. Even without a unitary theory, the notion of a prosecutor pursuing an accused who has the power to dismiss the prosecutor appears absurd.

For the aforementioned reasons, in the instance of the Watergate scandal, which gravely implicated the president, the United States resorted to a major deviation from American traditions, and arguably an unconstitutional one, with the creation by statute of a special prosecutor who would be partially independent of executive branch control. The result was a continuing, unresolved clash between presidential and congressionally-mandated prosecutorial authority, and ultimately the resignation of a president under threat of impeachment.

Central to the debate over the creation of a special prosecutor was the problem of accountability, particularly the accountability of a prosecutor working on highly politically-charged and electorally-significant matters. This concern was largely responsible for giving that office a very limited mandate and a short existence. The problem was not solved, and the special prosecutor's office was short-lived.

All of this brings us to what might well be called the Italian problem. Italian prosecutors have achieved a degree of independence unrivaled elsewhere and thus an unrivaled freedom from accountability. For very good reasons having to do with the powers of the Mafia and its interconnection with both elected and appointed government officials, crusading prosecutors striking at organized crime and government figures became Italian action heroes. ${ }^{23}$

The great problem that arises is that the initiation of prosecution or even of investigation that may lead to prosecution, particularly when it occurs during the political campaigns preceding elections, can give enormous partisan electoral advantage to the opponents of those candidates under prosecutorial scrutiny. ${ }^{24}$ And, inevitably, those under prosecutorial scrutiny will defend themselves by claiming that the prosecutors are either politically-motivated or driven by motives of personal self-aggrandizement. Particular prosecutors become both culture heroes and culture villains. They are, at times, independent forces of the rule of law against the corruption of politics, and at other times, part of that very corruption. ${ }^{25}$

23. See generally Alberti, supra note 21 .

24. See generally id.

25. See generally id. 
The problem of accountability remains acute. Extreme independence in the absence of effective accountability actually leads to a crisis of independence. As the prosecutors become deeply embroiled in their party and electorally-oriented politics, and the only available response to their actions is to publicly attack their actions as politically-motivated, the whole prosecutorial office tends to be delegitimized and public support, on which independence ultimately rests, is eroded.

Thus, neither the American style of direct electoral accountability, nor the Italian style of isolation from nearly all accountability, appears to resolve the independence-accountability paradox for prosecutors.

\section{INDEPENDENCE AND ACCOUNTABILITY OF TRIAL COURT JUDGES}

A range of recruitment, appointment, education, preservice and in-service training, and advancement arrangements designed to create judicial esprit de corps and separation from government and administration have been relatively successful in establishing and maintaining judicial independence in continental Europe. Judicial accountability, however, remains far more problematic. Individual judges are, to a degree, held accountable to the collectivity of judges, and in some countries, institutionalized in supreme judicial councils that include some nonjudicial members.26 Most countries have individual complaint procedures for judges comparable to those for other civil servants. ${ }^{27}$

The U.S. federal and state governments remain the great outlier. In the United States, one encounters a very large and complex spectrum of selection practices, which include: partisan election of trial judges for short terms; nonpartisan elections; yes-no plebiscites in which only the incumbent's name appears on the ballot; and various methods of appointment by state governors and the president, usually with participation by the upper house of the legislature and often with nominating or vetting roles assigned to professional legal associations or special commissions.

All of these complexities and variations reflect the American sense of paradox over judicial independence and accountability and show greater sensitivity to accountability issues than in Europe. Yet, even in the most electorally-oriented state systems within the United States, voters nearly always reelect incumbent judges and do so not because

26. See generally APPoINTING JUdGES IN AN AGE OF JUdiCIAL POWER: CRITICAL PERSPECTIVES From AROUND THE WORLD (Kate Malleson \& Peter H. Russell eds., 2006).

27. See, e.g., Setsuo Miyazawa, Administrative Control of Japanese Judges, 25 KOBE U. L. REV. 45 (1991) (Japan). 
they know anything about the incumbents or the challengers, or even recognize their names, but because the incumbents are incumbent. ${ }^{28}$ Very few incumbent judges have lost office. ${ }^{29}$ The few states that have used partisan elections have shown great uneasiness in using them and have sometimes abandoned them when real Republican versus Democratic judicial election campaigning arose. ${ }^{30}$ In general, U.S. citizens seem to believe that judges should be chosen on a merit basis, but that some opportunity should be retained to oust particular judges at stated intervals when a judge's actions have been so notably bad as to attract lasting public disapproval. ${ }^{31}$

Recently, the problem of judicial elections in the United States has taken on new urgency, largely as the result of the "adversarial legalism" noted earlier. Perhaps because of the jury system, the contingent fee system, the use of punitive damages, and the relative efficiency of U.S. courts, U.S. citizens and NGOs have become prone to sue business enterprises both to gain compensation for injuries inflicted and to supplement or replace government regulatory efforts deemed inadequate. Congress and state legislatures regularly encourage such litigation by enacting statutory provisions that authorize and encourage private lawsuits to enforce regulatory laws. ${ }^{32}$ The number and detail of those regulatory laws have greatly increased in recent years in response to environmental, health, safety, discrimination, and consumer protection concerns. The government itself enforces these laws through litigation in trial courts.

Although most of the cases involving large sums of money or major regulatory demands will go on to appellate courts, trial court fact findings and the amount of damages or fines may have a decisive impact on final outcomes. Plaintiff failure at trial will discourage other plaintiffs from coming forward.

Thus, the business community, faced with the risk of frequent and large adverse judgments, has now discovered a very strong interest in just who gets to be and stay a trial court judge. Previously, an incumbent judge up for reelection might face no opposition or only nominal opposition..$^{33}$ Given voter preferences for incumbents, the mere word incumbent next to his or her name on the ballot would insure

28. See generally James L. Gibson, Electing Judges: Surprising EfFeCts of CAMPAIGNING ON JUDICIAL LEGITIMACY (2012).

29. See generally id.

30. See generally id.

31. See generally id.

32. For example, most state and federal employment discrimination laws provide for private right of action.

33. See generally GIBSON, supra note 28; Lawrence Baum, Judicial Elections and Judicial Independence: The Voter's Perspective, 64 OHIO ST. L.J. 13 (2003). 
reelection. ${ }^{34}$ Now business interests are beginning to identify "antibusiness" judges, recruit high quality candidates to oppose them, and spend money on judicial election campaigns. Incumbent judges find themselves needing to spend money to counter their opponents' campaign spending. Incumbent judges are unlikely to have money of their own to spend because it is difficult for a sitting judge to solicit or even simply accept donations.

The whole U.S. pragmatic compromise on the independence-accountability problem, in which the incumbent judge is always reelected absent flagrant misconduct, is called into question. ${ }^{35}$ Undoubtedly, there will be mounting pressure to move away from the election of trial judges. ${ }^{36}$ There is also increasing concern about recusal norms as they relate to parties in a case who have made judicial campaign contributions.

Indeed there has always been a certain perversity of practice in the United States. In most states that elect judges, trial court judges serve for shorter terms than appeals judges. In some states, higher court judges are appointed and lower court judges are elected. Yet, if the rationale for electing judges is that they are lawmakers and that lawmakers should be elected in a democracy, higher court judges should be subject to more rigorous election requirements because they $\mathrm{mix}$ more lawmaking in with their dispute resolution than trial courts. Where career judiciaries exist and a central authority promotes and assigns judges to levels and locations of courts, trial court judicial independence may be threatened-lower court judges may seek to curry favor with their career controllers by deciding cases as those controllers might wish them to be decided. Fear of this has often led to moving judicial career control out of ministries of justice and into judicial corporate bodies, usually dominated by higher court judges. ${ }^{37}$ Yet, then the fear arises that the judicial independence of lower court judges may be compromised because lower court judges will decide cases in ways that higher court judges who control their careers may desire.

Why is it considered a compromise of judicial independence if lower court judges have high incentives to obey higher court judges? It is because of the civil law orthodoxy that, unlike the common law, civil law

34. See generally Baum, supra note 33 .

35. See Brandice Canes-Wrone, Tom S. Clark \& Jee-Kwang Park, Judicial Independence and Retention Elections, 26 J.L. ECON. \& ORG. 1, 18-19 (2010) (arguing that judicial retention elections create pressure for judges to cater to public opinion on pressing legal issues).

36. See id.

37. See generally Appointing Judges in the Age of Judicial Power: CRitical PERSPECTIVES FROM AROUND THE WORLD, supra note 26. 
does not know precedent. ${ }^{38}$ Every judge, in every case, is to go back to the words of the relevant legal text, usually a code provision or statute, as the sole authority for the case to be decided. If this practice of utilizing precedent is really correct, then no judge, no matter how low in the judicial hierarchy, should decide a case on the basis of how a judicial superior would wish it to be decided. The judge must make an independent, text-driven decision without fear that his career will suffer for it. This is why the French have the practice of cassation, ${ }^{39}$ in which, while a lower court decision is annulled on appeal, the case returns to that lower court for a new, independent judgment.

The French practice is, however, not really the practice, and so the problem is not really a problem. Even French law teachers now recognize that high court decisions sometimes make law, and that even in civil law systems the precedential value of higher court decisions must be recognized by lower courts if there is to be any uniformity, stability, and predictability in the law applied by the courts.

Collections of leading decisions have now appeared among the law texts taught to law students in many European states. Civil law trial judges now ignore the law propounded by higher courts at their peril. Whether that peril should consist only of cassation of their nonconforming decisions or manifest in their professional evaluations and other influences on their appointments to higher and more desirable judicial posts is in debate. To define judicial independence in terms of the total isolation of trial court judges from the need to follow the pronouncements of law issued by their appeals courts runs against the reality of the way civil law systems actually operate. Indeed, part of judicial accountability is the demand that lower court judges follow the law announced by higher courts. Of course, if high courts in authoritarian states are politically dominated, then trial court independence from high courts would be a step in the right direction.

\section{THE SCOPE OF APPEALS COURT ACCOUNTABILITY}

We begin here with the premise that appeals courts make law. Even on appeal, perhaps well over 90 percent of cases have a single, correct outcome derived by mere application of well-settled statutory or case law. Nevertheless, there are some cases in which the previous state of the law is ambiguous, self-contradictory, or nonexistent. In those

38. See generally SHAPIRO, supra note 5.

39. Cassation is a part of French law in which a decision is annulled or reversed with sovereign authority, thus "breaking the force and validity of a judgment." What is Cassation?, THE LAW DICTIONARY (last visited Feb. 18, 2013), http://thelawdictionary.org/cassation/. 
instances, the courts must, nonetheless, say what the law is, or, in other words, make the law. Precisely because unsettled legal issues tend to generate appeals, appeals courts will do more lawmaking than trial courts.

If the ratio of judicial independence to accountability should vary corresponding to the ratio of judicial conflict resolution to judicial lawmaking, then particular problems of accountability arise for appellate courts. Other than U.S. legal cultures, there does not appear to be much inclination on the part of other legal cultures to move toward judicial elections. Except on constitutional issues, many appeals courts are not held accountable, even to other judges. Highest courts, or courts with final or exclusive constitutional judicial powers, are typically accountable only through impeachment. There appears to be only mutual accountability of judges to one another provided by relatively large appellate panels. Although appellate work product is likely to come under some scrutiny and criticism by the academic legal community, overall accountability appears quite weak.

Perhaps here, too, however, there is a pseudo problem. No matter what the hymns to judicial independence are, when courts make law by "interpreting" or "applying" statutory law, they are not, and are not supposed to be, independent, but rather totally dependent agents of the legislature. Should it wish to, the legislature could always amend the judicially interpreted statute to "correct" the court's "misinterpretation" of the original statutory language.

Judicial independence means that courts should be shielded from intervention by individual legislators or even the legislature as a whole as to particular cases. ${ }^{40}$ However, independence does not preclude the legislature from changing future judicial outcomes by amending the general language of the statute. As courts of law, courts are supposed to be independent of legislative intervention as to each particular case before them, but not as to future cases, because the legislature is fully entitled to intervene by amending the statute.

Thus, judicial lawmaking by appellate courts is accountable to the elected legislatures at least in its future impact. There is, however, a major caveat. The legislatures of some fully developed democracies sometimes experience low legislative efficiency-that is, they have trouble passing laws quickly or at all. This inefficiency may result from constitutional checks and balances such as two house legislatures or from electoral and political dynamics that lead to weak, multiparty

40. See generally JUDICIAL INDEPENDENCE AT THE CROSSROADS: AN INTERDISCIPLINARY APPROACH, supra note 1; JUDICIAL INDEPENDENCE IN THE AGE OF DEMOCRACY, supra note 1; TARR, supra note 1; THE POLITICS OF JUDICIAL INDEPENDENCE: COURTS, POLITICS, AND THE PUBLIC, supra note 1; SollenbERGER, supra note 1; Carrington, supra note 1. 
coalition governments that find it difficult to attain majority votes in the legislature for their proposed statutes. Under such conditions, appellate courts and administrative bureaucracies are likely to promulgate much of the new law that needs to be made. This lawmaking will then be subject to little legislative accountability. A legislature that found it hard to make law in the first place is also likely to find it hard to make law to "correct" the lawmaking that the courts and the bureaucracies have made for it.

\section{ADMINISTRATIVE CoURTS As A MEANS To ENSURE INDEPENDENCE ${ }^{41}$}

Many of the non-English speaking countries have a separate or partially separate system of administrative courts. Even the English-speaking countries have proliferated many different administrative tribunals. ${ }^{42}$ There is a general and longterm tendency to endow these courts and tribunals with a high degree of independence even in the many countries that acknowledge that they are, and ought to be, somehow part of administration. ${ }^{43}$ In the United States, for instance, federal hearing officers have won for themselves the title of administrative law judge. Even where such administrative judges are not part of a rigorously separated administrative court system, they are frequently relatively insulated from the rest of the administrative agencies in which they work. For instance, persons who have assisted in the administrative agency's investigation of a particular person or enterprise are often prohibited from serving as hearing officers in the resulting trial-like procedure. ${ }^{44}$

In general, English-speaking countries have been somewhat suspicious of specialized administrative courts or other specialized courts, as opposed to courts of general jurisdiction. ${ }^{45}$ Even as these countries have increasingly turned to administrative tribunals, they have tended to provide for appeal from the tribunals to the regular courts. The general argument is that no matter what the formal separation is, administrative law and specialized court judges find themselves constantly and almost exclusively engaged in cases in which the government seeks to enforce the law to serve the public or general

41. For a discussion on the structure and practices of administrative courts and tribunals, see generally CoMPARATIVE ADMINISTRATIVE LAW (Susan Rose-Ackerman \& Peter L. Lindseth eds., 2010).

42. See generally id.

43. See generally id.

44. See generally id.

45. See generally LAWRENCE BAUM, SPECIALIZING THE CoURTs (2011). 
interest while the private sector opponent seeks its own private advantage by avoiding, even if not evading, the law.

It is argued that in such a context, administrative law judges, who are government officers and public servants themselves, are likely to internalize pro-government perspectives and in this sense become non-independent. Where an entirely separate system of administrative courts exists, the pro-government perspective will not be held in check by appeal. For such an appeal will be to still more judges of the same pro-government inclination as the initial hearing officer or administrative law trial judge.

The civil law response to this situation is highlighted by the high esteem in which councils of state are held in the southern European tier. The response is to have administrative law judicial cadres and judges of specialized courts combine the specific expert knowledge needed to understand government operations-that judges of general jurisdiction do not have-with an elite, professional, and legal esprit de corps that emboldens them to active intervention in administrative affairs. Certainly, the very high levels of expert knowledge needed to understand, let alone control, government regulation of an increasingly high-tech world would seem to favor specialized rather than generalist administrative judicial review bodies and specialized courts of first instance. ${ }^{46}$

\section{CONSTITUTIONAL JUdICIAL REVIEW AND DEMOCRACY}

It has been widely recognized that constitutional courts ${ }^{47}$ present special problems of judicial independence because of the inevitably political impact of their decisions because the typical, generally worded language of constitutions gives their judicial interpreters even greater lawmaking discretion than arises in much statutory interpretation, and because their decisions are more "final" than those of judges interpreting statutes. Legislators cannot "correct" faulty judicial interpretations of constitutional provisions as they can those of statutes by amending or repealing the statute through the normal legislative process. It has increasingly been argued that most constitutional decisions come down to judicial judgments of the reasonableness or proportionality of government actions by balancing constitutional values

46. See generally id.; F. Andrew Hanssen, Independent Courts and Administrative Agencies: An Empirical Analysis of the States, 16 J.L. ECON. \& ORG. 534 (2000).

47. Developed states generally follow the U.S. model in which all courts or the highest regular appeals courts have jurisdiction over constitutional questions or the "Kelsenian" model in which a single, separate constitutional court enjoys exclusive jurisdiction over such questions. See generally STONE SWEET, supra note 13. 
against government public policy goals. ${ }^{48}$ There could hardly be an instance of greater judicial discretion.

Fierce debates over the compatibility of constitutional judicial review and democracy have repeatedly been waged on both sides of the Atlantic Ocean. Perhaps the greatest historical threat to judicial independence in a fully developed democracy, Franklin D. Roosevelt's court packing scheme in the United States, was engendered by the Supreme Court's constitutional decisions. Similar proposals are afloat today. Major crises of judicial independence have occurred in developing democracies as a result of constitutional court decisions with high political impact, although some of these crises spring from decisions based on statutory, rather than constitutional, grounds.

Leaving election decisions aside, there are three areas of constitutional decision-making that tend to generate threats to judicial independence. The first area consists of federalism decisions involving the constitutional allocation of powers between a central government and its member states. In general, the court's independence in making such decisions, whether they favor the central government or member state governments, is likely to survive even heated attacks. Federalisms are cartels in which the most favorable position for any member is that all other members obey the rules while it cheats. For instance, it will be strongly in the interest of a coal producing member state to fan imports of coal from other states-that is, to cheat on an interstate commerce or "free trade" clause, while all other states obey the clause by allowing entry of coal from the cheating state to its own internal market. Thus, the survival of the cartel depends on strong surveillance and repression of cheating.

Federalism review by a constitutional court is an obvious and usually effective anticheating mechanism. Thus, conflicts between the court and any one member state are likely to result in support of the court by all other member states. The historical experiences of the European Court of Human Rights and the European Court of Justice are very instructive in this regard. ${ }^{49}$ Yet, occurrences in the former Soviet Empire, in Canada, and in the United States during the Civil War suggest that constitutional courts enforcing federalism may come

48. Alec Stone Sweet \& Jud Mathews, Proportionality Balancing and Global Constitutionalism, 47 ColUM. J. TransnaT'L L. 72, $73-76$ (2008). See Martin Shapiro, Judicial Review Global, in La Ciencia Del Derecho Procesal Constitucional [The SCIENCE OF PROCEDURAL CONSTITUTIONAL LAW] 889, 890 (Eduardo Ferrer Mac-Gregor \& Arturo Zaldivar Lelo de Larrea eds., 2008) (Mex.) (describing how courts across the globe apply a proportionality balancing test).

49. See generally A EUROPE OF RIGHTS: THE IMPACT OF THE ECHR ON NATIONAL LEGAL Systems (Helen Keller \& Alec Stone Sweet eds., 2009). 
under extreme stress when one or more members of the federal cartel prefers dissolution. The Canadian "Notwithstanding" Clause, which allows member state legislatures to override some adverse central constitutional court decisions, also indicates the strong threat to independence that federalism cases may entail. ${ }^{50}$

A second area of potential conflict involves division of powers. Jurisdiction over the constitutional division of powers within the central government potentially pits constitutional courts against legislative or executive branches with far more immediate and concrete powers than those of the judiciary. ${ }^{51}$ The risk that exercises of judicial independence that produce decisions unfavorable to the powers of the legislature or executive will generate reprisals is obvious. In most developed democracies, constitutional courts have deliberately avoided open clashes with the executive branch over the limits of executive authority and have been cautious in refereeing disputes between executive and legislative branches, leaving them largely to openly political processes. In developing democracies, overweening executives may pose serious threats to the constitutional division of powers, and courts have sometimes become, perhaps unavoidably, less cautious than they might have been in upholding constitutional limitations on assertions of executive power. In such instances, judicial independence may be seriously threatened, either by executive intervention in a particular case or by executive attacks on judges or on the judicial institution.

The third area of potential conflict is individual rights. Where a court strikes down legislation on rights grounds, issues of judicial thwarting of the majority and of judicial, democratic accountability rise dramatically. In these instances, the court openly pits itself against democratically elected governments and purports to speak with finality. This scenario would appear to be the most dangerous situation any court, constitutional or otherwise, could face.

There have been two responses to this perceived problem. ${ }^{52}$ The first is that of "judicial self-restraint," in which the judges are urged to be extremely cautious or even abandon judicial review altogether. ${ }^{53}$ To be sure, motives here are mixed. Some proponents of judicial self-restraint are simply opposed to the judicial elaboration of new individual rights. Others are dedicated to unlimited majoritarian democracy. Many

50. See generally Law, Politics and the JUdiclal Process in Canada (F.L. Morton ed., 3d ed. 2002).

51. See, e.g., Alexander M. Bickel, The Least Dangerous Branch: The Supreme COURT AT THE BAR OF POLITICS (1962).

52. This perceived problem is generated by judicial vetoes of legislation enacted by elected legislatures but possibly infringing on constitutionally protected rights.

53. See, e.g., LEARNED HAND, THE BILL OF RIGHTS (1964). 
proponents, however, see judicial self-restraint as a pragmatic device protecting constitutional courts from public attack for decisions thwarting strong public desires expressed in legislation. ${ }^{54}$ These proponents see constitutional review related to rights as the most dangerous judicial activity in terms of potentially engendering political invasions of judicial independence. ${ }^{55}$

Certainly, the most successful constitutional courts have exhibited a certain strategic sense concerning when to, and when not to, press forward vigorously on rights issues. Those who are not self-restrainers argue that the global enthusiasm for human rights is so great that it does, and will, protect rights-ambitious courts.56 They point to the extraordinary new enthusiasm for constitutional bills of rights and their equivalents, and for judicial protection of those rights in both the nation states of Eastern Europe and transnational institutions. ${ }^{57}$ The European Court of Human Rights, the European Court of Justice, the German and Italian Constitutional Courts, and the constitutional courts of other EU member states have flourished as rights protectors. ${ }^{58}$ France has recently experienced a virtual revolution in its judicial institutions and processes for protecting human rights. ${ }^{59}$ Israel has vigorous constitutional rights review even without a formal constitutional bill of rights. ${ }^{60}$

There has been a globalization of constitutional bills of rights and constitutional judicial rights review. ${ }^{61}$ Nevertheless, the enthusiasm for rights may appear to be sufficient enough to support vigorous judicial implementation and even expansion of constitutional rights, at least in developed democracies, without unreasonable risks of invasion into judicial independence.

The problem of democratic accountability for independent constitutional courts does not appear a wholly insolvable one in spite of the "finality" of constitutional decisions. The old American folk wisdom that the Supreme Court follows the election returns, or that the Court never strays far from the governing political coalition, appears roughly

54. See generally AleXANDer M. BiCKel, The Supreme CourT AND THE IDEA OF PROGRESS (1978).

55. See generally id.

56. See generally BETH A. SIMMONS, MOBILIZING FOR HUMAN RIGHTS: INTERNATIONAL LAW IN DOMESTIC POLITICS (2009).

57. See generally id.

58. See generally THE WORLDS OF EUROPEAN CONSTITUTIONALISM (Gráinne de Búrca \& J.H.H. Weiler eds., 2011).

59. See generally Alec Stone, The Birth of Judicial Politics in France: The CONSTITUTIONAL COUNCIL IN COMPARATIVE PERSPECTIVE (1992).

60. See generally SUZIE NAVOT, THE CONSTITUTIONAL LAW OF ISRAEL (2007).

61. See generally THE WORLDS OF EUROPEAN CONSTITUTIONALISM, supra note 58. 
true on both sides of the Atlantic Ocean. The separate, and distinctly political, appointment processes for constitutional court judges and term limits provide a pragmatic balance between independence and accountability. The wide range of ease or difficulty in constitution amending processes among Western polities signals continuing concerns for such pragmatic adjustments.

The uneasiness over a small body of nonelected persons, chosen largely from a rather narrow stratum of society, making fundamental, and in some sense final, decisions of public policy is not going to go away. Neither is the enthusiasm for the "constitutional" aspect of "constitutional democracy," nor for "rights" and for some means of enforcing them. The paradox of independence and accountability is not going to go away.

\section{INDEPENDENCE AND ACCOUNTABILITY}

In summary, if we take a global view of more or less fully developed democracies, we encounter the basic paradox of judicial independence everywhere. The fundamental task of courts is conflict resolution which, to be successful, requires judicial independence. ${ }^{62}$ Successful conflict resolution also requires some quantum of judicial lawmaking because judicially imposed resolutions are most easily accepted when they appear to be the product of preexisting legal rules. ${ }^{63}$ Judges, therefore, will "interpret" or make such rules when deciding cases where a sufficiently applicable rule is not otherwise provided. ${ }^{64}$ In a democratic polity, such lawmaking demands some degree of democratic accountability.

There is a wide array of pragmatic, never wholly satisfactory, and frequently altered responses to the paradox. There is judicial selection by a wide array of electoral arrangements, ranging from partisan elections to short terms of office to long terms followed by yes-no plebiscites for further terms. Alternatively, judicial selection may be by appointment by political executives-with or without legislative confirmation-by a judicial council composed of judges and lay members, or by cooption by the incumbent judges. Appointments may be either from a universal-although typically professionally qualifiedpool, from a pool of candidates preselected either by special qualifications (e.g. law professors, senior practitioners, government lawyers of a certain rank), by civil service style examinations, or by

62. See generally SHAPIRO, supra note 5.

63. See generally id.

64. See generally id. 
some special body representing particular interests. The organized bar may or may not play a part in judicial selection.

Similarly, individual judicial career trajectories may be controlled by a ministry of justice headed by a political appointee or by a judicial council, or they may be nonexistent in the sense that a judge appointed to any particular court may have no expectation of moving from it to another. At one extreme is the Italian judicial prosecutor arrangement referred to earlier Section V.

In democracies that have institutionalized constitutional judicial review, the sporadic debates that arise over the democratic legitimacy of such review are clear evidence of the difficulty of resolving or even compromising the independence-accountability paradox. In addition to the independence-accountability paradox that bedevils democratic regimes, a second paradox, noted earlier, is particularly relevant to authoritarian regimes and regimes that are tentatively moving toward democracy. Judicial independence should be a goal for all regimes, but each regime should also have the goal that the courts decide cases legally rather than arbitrarily. Yet courts of law are not independent; they are the agents or dependents of whoever makes the law. There has been much emphasis on the possibility that even highly protective constitutional and statutory rights guarantees may be meaningless in the absence of a truly independent judiciary to enforce them. Thus, there is tremendous stress on independence as a definitional characteristic of courts.

That being said, there are darker aspects of this scenario worth considering. First, a truly independent judiciary may garner a strong popular perception of institutional legitimacy. If, however, such a judiciary is part of an authoritarian, repressive regime, it lends its legitimacy to the perceived institutional legitimacy of the authoritarian regime itself. Second, a truly independent judiciary, acting according to the rule of law, lends not only its legitimacy, but also its implementation facilities to the laws, even if those laws are repressive, exploitative, or advantageous to certain political, economic, or social interests. A well-nurtured global myth of judicial independence obscures the reality that courts of law are agents of a principal and that the principal may be an authoritarian, repressive regime. ${ }^{65}$ The independence flag contributes to the perceived legitimacy of whatever law the courts enforce. A terrible law sounds better in the mouth of the "independent" judge than in the mouth of a political administrator, and everything

65. See generally RULE By LAW: THE POLITICS OF COURTS IN AUtHoRITARIAN REgimeS, supra note 15 . 
about the judges' training and institutional interests leads them to make it sound as good as they can.

Third, lawyers, and particularly judges, love procedure. Even a substantively very bad law is somewhat less bad if it is procedurally fair. Yet, the decision by an independent court that the fair procedures required by a statute have been followed may provide a legitimacy-enhancing judicial imprimatur to a law that is substantively horrendous. For instance, laws that empower a government to severely impair the rights or interests of particular groups in the interest of the politically dominant may well be upheld by an independent court on procedural grounds where consultation has taken place. Yet, the court's procedural approval will almost unavoidably be publicly read as a general approval, thus providing added legitimacy to the law. ${ }^{66}$ Along similar lines, no matter how much the U.S. Supreme Court insists that when it finds a statute to be constitutional it is not necessarily saying that the statute is a good thing, the headlines always say otherwise. The difference between "upholding" and "approving" is not one easily grasped by even the attentive public.

As the study of law and courts moves further and further into the realm of authoritarian regimes, it is clear that support for judicial independence is a two-edged sword. Authoritarian regimes can employ the myth and even the reality of judicial independence to legitimize their invasions of human rights. ${ }^{67}$ The combination of over-generalized slogans of rule of law, courts of law, and judicial independence is an invitation to authoritarian regimes to disguise their abusive practices in judicial draperies. On the other hand, a well-established tradition of judicial independence may assist a transition from colonial to democratic rule. 68

\section{CONCLUSION}

Anyone desiring absolute judicial independence can easily imagine the institutional arrangements to achieve it, although even these arrangements would be ineffective in the absence of strongly held popular and elite values of independence. Judges would be appointed by cooption by the sitting judges. Each judge would serve until a fixed retirement age in the office to which he was initially appointed with

66. I am indebted to Pablo Reuda for highlighting this point.

67. See generally RULE BY LAW: THE POLITICS OF COURTS IN AUTHORITARIAN REgIMES, supra note 15.

68. See generally JENS MEIERHENRICH, THE LEGACIES OF LAW (2008) (describing how the courts in apartheid South Africa resisted the apartheid state by applying basic principles of English common law). 
increases in salary based solely on length of service. Case assignment would be random. Ex parte communication and any gifts would be banned. Judges might only be dismissed for conviction of a serious crime in regular criminal proceedings. All of these things would be constitutionally guaranteed and the constitution would be very difficult to amend. Yet, given the extent to which contemporary judges make law, it is hard to see how even those who believe that majority rule and electoral democracy should be severely constitutionally limited could support such an extreme government of judges.

It is also easy to imagine a set of institutions supporting complete, political accountability for judges. Either all judicial offices would be filled by the elected chief political executive and all judges would serve at his favor, or all judicial offices would be filled in the same manner as seats in the house of the legislature. There seems to be no substantial body of opinion devoted to this degree of democratization of the judiciary. Those strongly opposed to judicial lawmaking typically seek to limit it as much as possible rather than subject it to strict electoral accountability.

One reason, or rather set of reasons, that judicial independence is difficult to achieve is that all good government is difficult to achieve, no matter what formal political institutions are established. Another reason, however, is that hardly anyone would want absolute judicial independence. We must all settle for one of the large varieties of mixes of independence and accountability that various developed, democratic states have adopted, none of which is entirely satisfactory. 
